\title{
PRODUCTION AND EXPERIMENTAL INVESTIGATION OF BALLISTIC PERFORMANCE OF LAMINATED HYBRID COMPOSITES
}

\author{
[C. Yanen, M.Y. Solmaz]
}

\begin{abstract}
This paper presents studies on usability of multilayered hybrid composite as personal armor material. In the scope of study, 4 hybrid composite materials with different number of layers and thickness have been produced by using three different type of fabric. Then, ballistic tests have been performed and results have been investigated. The ballistic tests have been performed by using Beretta and 9 mm FMJ bullet to the international standards (NIJ 0101-06). In the ballistic tests, the speed of bullets and the depth of penetration (DOP) occurring on the test samples have been measured and the damages have been assessed. First 2 test samples with [Glass fiber $_{10} /$ Aramid fiber $_{10} /$ Carbon fiber $_{10}$ ] sequence and 30 layers have been produced, the ballistic tests have been performed and investigated. After observing the success of these two test samples, other two test samples have been produced by reducing the number of layers to 21 with [Glass fiber $_{7} /$ Aramid fiber $_{7} /$ Carbon $\left._{\text {fiber }}\right]$ ] sequence.
\end{abstract}

Keywords-Hybrid composite, Ballistic performance, Armor material

\section{Introduction}

Nowadays, fiber fabrics are widely used in personal armor material production due to lightness, impact resistance and high damping capabilities. There are numerous types of fabrics used in ballistic applications and plain woven unidirectional fabrics are the most commonly used types [1].

Textiles produced are widely used in engineering applications due to their lightweight, impact resistance and high energy absorption ability, properties which make them especially useful for the production of personal body armor. There are a number of types of ballistic textiles, but plainwoven fabrics and unidirectional laminates are the most commonly used textiles for bulletproof vest inserts.

Plain woven fabrics are composed of $90^{\circ}$ interwoven warp and weft fibers. Unidirectional fabrics are non-woven fabrics in which fibers are lined up in one direction and combined by sutures.

Materials used as personal armor are subjected to some tests to make sure their competence. These tests are carried

Cenk YANEN

Firat University

Elazığ/Turkey

Murat Yavuz SOLMAZ

Firat university

Elazı $\breve{g} /$ Turkey out according to some standard. In this study, NIJ 0101.06 has been taken as reference for measuring the ballistic performance. According to this standard, to consider the armor successful there are two main criteria. One of these criteria is, the armor has to stop the bullet. The other criterion is, the armor has to protect the person from damages of internal organs and internal bleeding.

Personal body armors must meet a number of requirements, some of which are specified in standards [2]. According to these standards, the primary task of ballistic inserts is to stop the projectile. The second and equally important issue is to limit deflection of the body armor which can cause nonpenetrating injuries to internal organs, referred to as blunt trauma [3].

To avoid the second task, the depth of penetration of armor is measured after ballistic tests. The depth of penetration obtained in the ballistic tests must be $44 \mathrm{~mm}$. Otherwise, the test sample is considered as failed even if it is not perforation [4].

Mines et al., investigated the damage mechanisms and energy dissipation capability of three different number of layers $\pm 45^{\circ}$ fiber woven E-glass samples with polyester resin matrix. They observed in their experiments that with the higher number of layers the amount of dissipation energy increased [5]. Gustin et al., made impact test of Kevlar and carbon fiber combination of sandwich composite samples. They obtained different carbon fiber/Kevlar, carbon fiber/hybrid combinations by changing the material at the impact surface. They used carbon fiber for rear surface in all their tests and as the main purpose of their study, they observed if there is an improvement when Kevlar or hybrid is used instead of the carbon fiber at the front surface. In their study, they also used polyurethane foam filled honeycomb structure produced by Canadian Mikor firm as middle layer. They performed the tests with Instron Dynatup $9250 \mathrm{HV}$. As a result of their study, they observed that the impact strength of the test samples increased about $10 \%$ when Kevlar and hybrid were used at the front surface compared to carbon fiber [6].

The aim of this study is to produce layered hybrid composites for personal body armor and to ensure high ballistic resistance and lightness. In this study, hybrid composite test samples have been produced and ballistic tests have been performed according to NIJ 0101.06 standard and the results have been investigated. The ballistic tests have been performed by using Beretta gun and $9 \mathrm{~mm}$ FMJ bullet from $5 \mathrm{~m}$ distance. In this study we have focused on if the test samples have been successful according to mentioned NIJ 0101.06 standard. 


\section{Methods}

\section{A. Test Sample Production}

In this study 4 hybrid layered composite test samples have been produced. Composite materials, essentially consist of reinforcement material and matrix material. Carbon fiber, glass fiber and aramid fiber have been used for reinforcement material. The properties of these fabrics are given in Table 1. As matrix component Hexion MGS L326 polyester resin and Hexion H265 hardener have been used. Polyester resin and hardener mixing ratio hs been set to $4 / 1$, as stated in the manufacturer's catalog [7].

TABLE 1: The fiber fabric used in sample production

\begin{tabular}{lll}
\hline Fabric Name & Fabric Type & Denstiy $\left[\mathrm{gr} / \mathbf{m}^{2}\right]$ \\
\hline Carbon Fiber & Unidirectional $0^{\circ}$ & 300 \\
Carbon Fiber & Unidirectional $45^{\circ}$ & 400 \\
Glass Fiber & Unidirectional $0^{\circ}$ & 300 \\
Glass Fiber & Unidirectional 45 & 460 \\
Aramid Fiber & Plain Woven & 410 \\
\hline
\end{tabular}

For producing the composites samples hand lay-up method has been preferred. In this method, the fabric have been laid and polyester resin-hardener mixture have been used. Then the samples have been placed in a hydraulic press and pressed at 20 bar pressure. The test samples have been cured by increasing the temperature gradually from 20 $\mathrm{C}^{\circ}$ to $110 \mathrm{C}^{\circ}$ in 4 hours. The schematic of test sample is given in Fig. 1 [8].

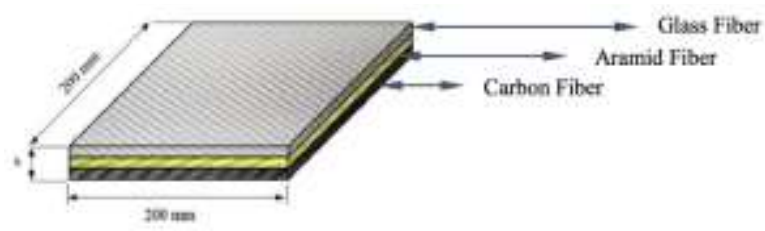

Figure 1. The schematic of the structure of [Glass/Aramid/Carbon] layered hybrid polyester resin matrix

The properties of layered hybrid composite produced in Firat University Mechanical Laboratory are given in Table 2.

TABLE 2. Properties of layered hybrid composite

\begin{tabular}{lllll}
\hline Name & Material & $\begin{array}{l}\text { Number } \\
\text { of layers }\end{array}$ & $\begin{array}{l}\text { Weight } \\
\text { [gr] }\end{array}$ & $\begin{array}{l}\text { Density } \\
{\left[\mathbf{g r} / \mathbf{c m}^{3} \text { ] }\right.}\end{array}$ \\
\hline B1 & $\begin{array}{l}\text { [Glass }\left(45^{\circ}\right) / \text { Aramid } \\
\left.\text { (plain)/Carbon }\left(45^{\circ}\right)\right]\end{array}$ & 30 & 818 & 1.57 \\
B2 & $\begin{array}{l}\text { [Glass }\left(0^{\circ}\right) / \text { Aramid } \\
\left.\text { (plain)/Carbon }\left(0^{\circ}\right)\right]\end{array}$ & 30 & 656 & 1.49 \\
B5 & $\begin{array}{l}\text { [Glass }\left(45^{\circ}\right) / \text { Aramid } \\
\left.\text { (plain)/Carbon }\left(45^{\circ}\right)\right]\end{array}$ & 21 & 554 & 1.54 \\
B6 & $\begin{array}{l}\text { [Glass }\left(0^{\circ}\right) / \text { Aramid } \\
\left.\text { (plain)/Carbon }\left(0^{\circ}\right)\right]\end{array}$ & 21 & 468 & 1.63 \\
\hline
\end{tabular}

\section{B. Ballistic Test}

Ballistic tests have been carried out by considering some standards. In the experimental study, National Institute of Justice (NIJ) has been taken as reference in the tests of the ballistic performance of composite samples. According to NIJ 0101.06 Level II-A standard, in the shots from $5 \mathrm{~m}$ by using $9 \mathrm{~mm}$ FMJ bullet, the bullet speed has to be $373 \pm 9.1$ $\mathrm{m} / \mathrm{s}$ (NIJ 0101.06). The speed of the bullet has been determined by using Chrony F1 Master chronograph in the tests. According to NIJ 0101.06 standard, to consider the test sample successful, the bullet used in the test have to stay in the test sample and the depth of penetration have to be maximum $44 \mathrm{~mm}$. For the depth of penetration above 44 $\mathrm{mm}$, the test sample is considered to be unsuccessful even if it is not perforation. The ballistic tests have been performed by the same person to make sure that carrying out the tests in the same condition. The experimental setup is shown in Fig. 2. The kinetic energy of the bullet for mass $(\mathrm{m})$ and the impact velocity $(\mathrm{V}), \mathrm{E}_{\mathrm{k}}$ is: [9]

$$
E_{k}=\frac{1}{2} m V^{2}
$$

s.

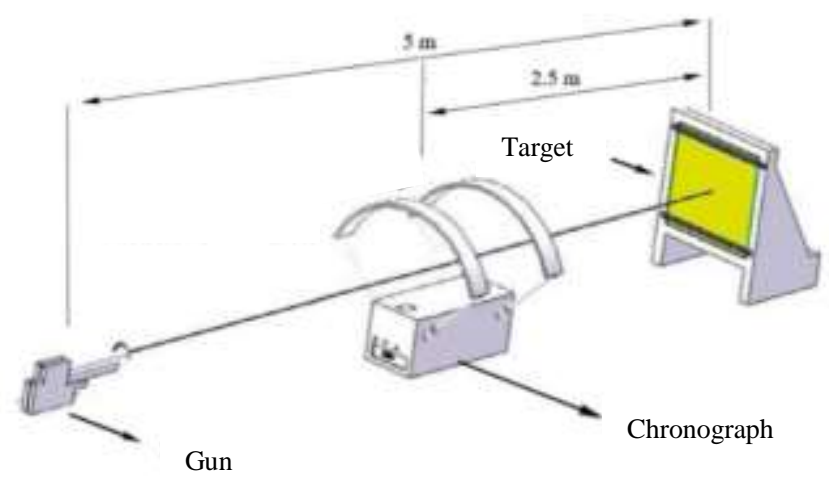

Figure 2. Schematic view of the ballistic test system

\section{Results}

In this study, the ballistic tests of produced samples with the reference of NIJ 0101.06 standard have been performed. Four shots have been performed to each test sample. The first stage of the study, two 30 layered hybrid composite structures with $\quad\left[\operatorname{Glass}\left(45^{\circ}\right)_{10} \quad / \text { Aramid(plain }\right)_{10}$ $/$ Carbon $\left.\left(45^{\circ}\right)_{10}\right]$ and $\left[\operatorname{Glass}\left(0^{\circ}\right)_{10} \text { /Aramid (plain) }\right)_{10}$ $/$ Carbon $\left(0^{\circ}\right)_{10}$ ] lineup have been produced and the ballistic tests have been performed. The photos of the 30 layered test samples after the ballistic tests are shown in Fig. 3 and Fig. 6.

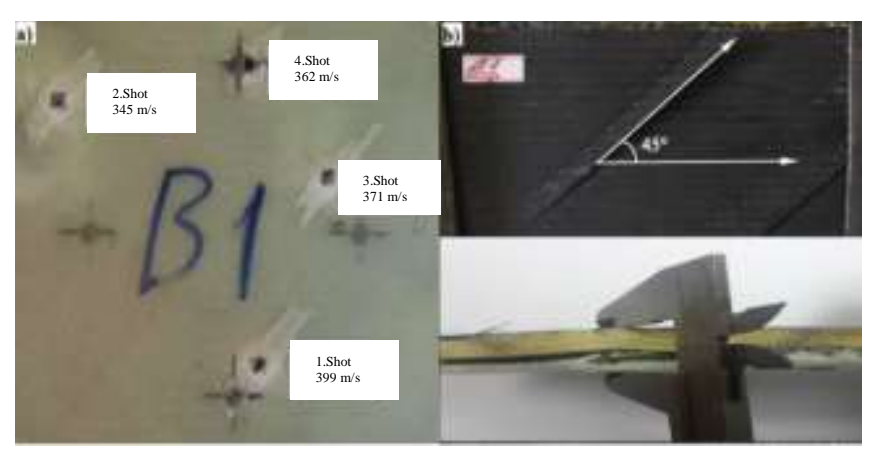

Figure 3. [Glass $\left(45^{\circ}\right)_{10} /$ Aramid (plain $)_{10} /$ Carbon $\left(45^{\circ}\right)_{10}$ ] test sample a) front view $b$ ) rear view c) measurement of DOP

Bullet speed and other results of belonging to sample that has $\left[\right.$ Glass $\left.\left(45^{\circ}\right)_{10} / \operatorname{Aramid}(\text { plain })_{10} / \operatorname{Carbon}\left(45^{\circ}\right)\right]$ sequence has been given in Table 3 . 
TABLE 3: Ballistic test result of B1 sample

\begin{tabular}{ccccc}
\hline \multicolumn{5}{c}{ Sample Sequence: $\left[\text { Glass }(\mathbf{4 5})^{\circ}\right)_{10} /$ Aramid $_{\left.(\mathbf{p l a i n})_{\mathbf{1 0}} / \text { Carbon }\left(\mathbf{4 5}^{\circ}\right)_{10}\right]}$} \\
\hline $\begin{array}{c}\text { Shot } \\
\text { Number }\end{array}$ & $\begin{array}{c}\text { Bullet } \\
\text { Velocity } \\
(\mathbf{m} / \mathbf{s})\end{array}$ & $\begin{array}{c}\text { Kinetic } \\
\text { Energy } \\
(\mathbf{N m})\end{array}$ & $\begin{array}{c}\text { Depth of } \\
\text { Penetration } \\
(\mathbf{m m})\end{array}$ & Evaluation \\
\hline 1 & 399 & 635,78 & 6,20 & No Perforation \\
2 & 345 & 476,19 & 4,50 & No Perforation \\
3 & 371 & 551,30 & 5,90 & No Perforation \\
4 & 362 & 523,59 & 5,50 & No Perforation \\
& & & & \\
Average & $\mathbf{3 6 9}$ & $\mathbf{5 4 6 , 7 1}$ & $\mathbf{5 , 5 3}$ & \\
\hline
\end{tabular}

Ballistic limit of sample named B1 has been observed between $345 \mathrm{~m} / \mathrm{s}$ and $399 \mathrm{~m} / \mathrm{s}$. All of the fired shots have completed successfully as all of them have been shot onto the plate. Because of the lamination sequence of the rearmost carbon fiber cloth is $45^{\circ}$, which functions as a support plate, fiber damage has been observed at directions $\pm 45^{\circ}$ on the plate. Average firing speed has been measured at $369 \mathrm{~m} / \mathrm{s}$ on shot to this sample. After ballistic test the shot that puncture didn't happen, depth of penetration in back face of plate was measured with caliper and confirmed. Depth of penetration value got from tests is $5,53 \mathrm{~mm}$. According to NIJ Level II-A this sample provide protection. Graphic of this sample is given in the Fig. 4.

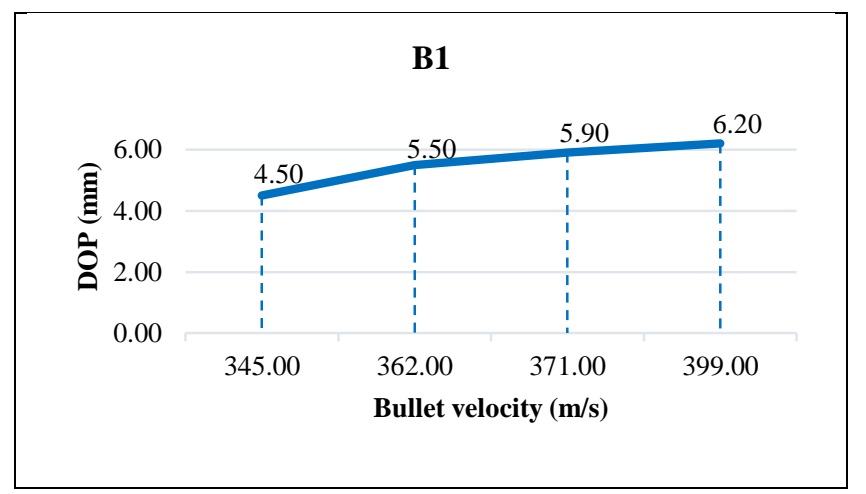

Figure 4. Graphic of bullet velocity-depth of penetration

When examined the graphic it is seen that depending on increasing bullet velocity depth of penetration is raising. After Ballistic tests sections were taken from the nearest place to the bullet and damage types were investigated. Photo of the shot number 2 that belong to sample B1 is given in Fig. 5.

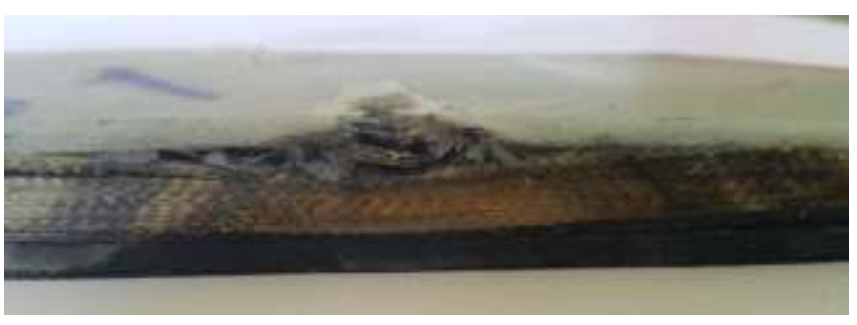

Figure 5. Sectional view of second shot

After shot no penetration is happened. Core of bullet by not passing glass fiber stayed between this plates. In area where bullet caused impact it caused fiber rupture and delamination of Aramid plates after glass fibers.

Second sample that ballistic test of it performed is [Glass $\left(0^{\circ}\right) 10 /$ Aramid (plain) $\left.10 / \operatorname{Carbon}\left(0^{\circ}\right) 10\right]$ sequenced $\mathrm{B} 2$.Ballistic test photo of sample B2 is given in Fig. 6 .

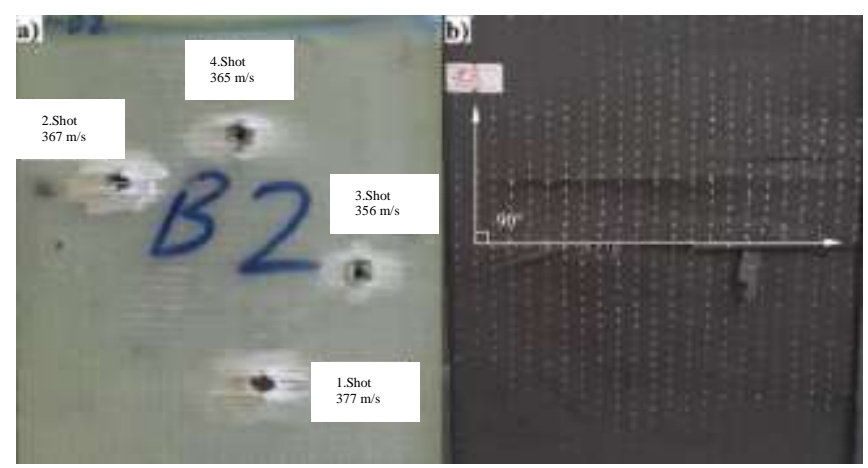

Figure 6. [Glass $\left(0^{\circ}\right) 10 /$ Aramid (plain) $10 /$ Carbon $\left.\left(0^{\circ}\right) 10\right]$ test sample a) front view b) rear view

Bullet speed and other results of belonging to sample that has $\left[\operatorname{Glass}\left(0^{\circ}\right)_{10} / \operatorname{Aramid}(\text { plain })_{10} / \operatorname{Carbon}\left(0^{\circ}\right)\right]$ sequence has been given in Table 4 .

TABLE 4: Ballistic test result of B2 sample

\begin{tabular}{ccccc}
\hline \multicolumn{5}{c}{ Sample Sequence: $\left[\text { Glass }\left(\mathbf{0}^{\circ}\right)_{\mathbf{1 0}} / \text { Aramid (plain) }\right)_{\mathbf{1 0}} /$ Carbon $\left.\left(\mathbf{0}^{\circ}\right)_{\mathbf{1 0}}\right]$} \\
\hline $\begin{array}{c}\text { Shot } \\
\text { Number }\end{array}$ & $\begin{array}{c}\text { Bullet } \\
\text { Velocity } \\
(\mathbf{m} / \mathbf{s})\end{array}$ & $\begin{array}{c}\text { Kinetic } \\
\text { Energy } \\
(\mathbf{N m})\end{array}$ & $\begin{array}{c}\text { Depth of } \\
\text { Penetration } \\
(\mathbf{m m})\end{array}$ & Evaluation \\
\hline 1 & 377 & 569,55 & 8,45 & No Perforation \\
2 & 367 & 539,59 & 7,40 & No Perforation \\
3 & 356 & 507,83 & 5,00 & No Perforation \\
4 & 365 & 533,34 & 6,00 & No Perforation \\
& & & & \\
Average & $\mathbf{3 6 7}$ & $\mathbf{5 3 7 , 5 8}$ & $\mathbf{6 , 7 1}$ & \\
\hline
\end{tabular}

None of shots to sample named B2 caused puncture and this sample is accepted as successful. Because of blackface carbon fiber fabric missioned as support plate is $0^{\circ}$ no horizontal fiber damage happened. Ballistic limit of Plate named B1 is appraised between $356 \mathrm{~m} / \mathrm{s}$ and $377 \mathrm{~m} / \mathrm{s}$. According to shots that made average depth of penetration is $6,71 \mathrm{~mm}$ corresponding to $367 \mathrm{~m} / \mathrm{s}$ bullet velocity. According to NIJ level II-A standard this sample verify protection. Graphic of bullet velocity-depth of penetration value is give in Fig. 7.

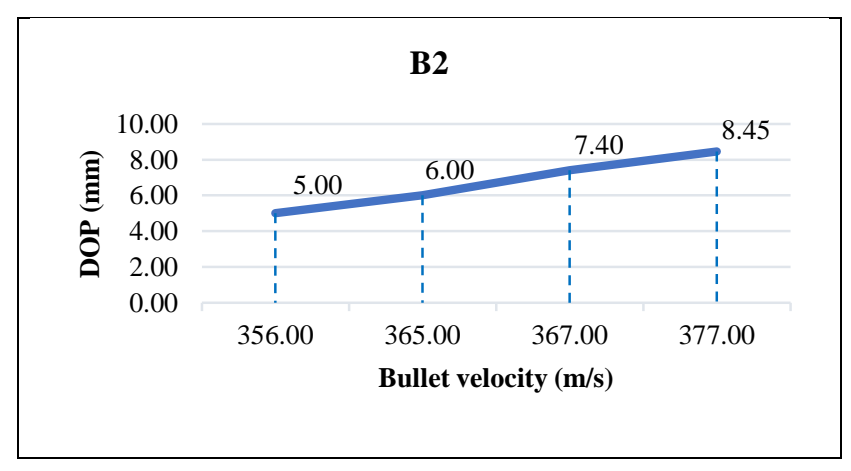

Figure 7. Graphic of bullet velocity-depth of penetration

For using and manufacturing of personal body armor with ballistic success another important criteria is lightness. 
After ballistic success of first 30 layered two samples' number of layer was reduced and targeted for lightness. Layer number of Sample named B1 and B2 were reduced to 21 without chosen fabric changed. One of first 21 layered sample is $\left[\operatorname{Glass}\left(45^{\circ}\right)_{7} / \operatorname{Aramid}(\text { plain })_{7} / \operatorname{Carbon}\left(45^{\circ}\right)_{7}\right]$ sequenced B5 sample. Sample that sequenced $\left[\operatorname{Glass}\left(0^{\circ}\right)_{7} / \operatorname{Aramid}(\text { plain })_{7} /\right.$ Carbon $\left.\left(0^{\circ}\right)_{7}\right]$ is second 21 layered sample. Ballistic tests of this samples' made according to NIJ 0101.06 standard shots were made from distance of $5 \mathrm{~m}$ and by using FMJ bullet and results investigated. Four shots were performed to 21 layered plates. Test results photos of B5 sample is given in the Fig. 8 . Bullet velocity and kinetic energy values that calculated with this velocities is defined by chronograph between center point of target and weapon given in table 4 .

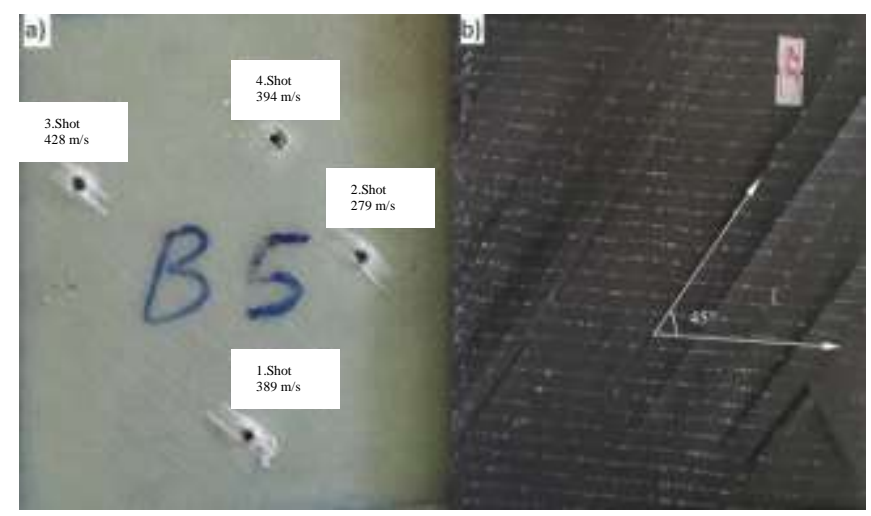

Figure 8. [Glass $\left(45^{\circ}\right)_{7} /$ Aramid (plain $\left.)_{7} / \operatorname{Carbon}\left(45^{\circ}\right)_{7}\right]$ test sample a) front view b) rear view

TABLE 5: Ballistic test result of B5 sample

\begin{tabular}{ccccc}
\hline \multicolumn{4}{c}{ Sample Sequence: $\left[\right.$ Glass $\left(\mathbf{4 5}^{\circ}\right)_{7} /$ Aramid $(\text { plain })_{7} /$ Carbon $\left.\left(\mathbf{4 5}^{\circ}\right)_{7}\right]$} \\
\hline $\begin{array}{c}\text { Shot } \\
\text { Number }\end{array}$ & $\begin{array}{c}\text { Bullet } \\
\text { Velocity } \\
(\mathbf{m} / \mathbf{s})\end{array}$ & $\begin{array}{c}\text { Kinetic } \\
\text { Energy } \\
(\mathbf{N m})\end{array}$ & $\begin{array}{c}\text { Depth of } \\
\text { Penetration } \\
(\mathbf{m m})\end{array}$ & Evaluation \\
\hline 1 & 389 & 606,00 & 8,00 & No Perforation \\
2 & 279 & 312,28 & 5,70 & No Perforation \\
3 & 428 & 729,40 & 10,60 & No Perforation \\
4 & 394 & 621,28 & 9,35 & No Perforation \\
& & & & \\
Average & $\mathbf{3 7 2}$ & $\mathbf{5 6 7 , 2 4}$ & $\mathbf{8 , 4 1}$ &
\end{tabular}

None of shots to first of 21 layered sample caused perforation and sample verified as successful. Average of 4 shot to sample B5 is $372 \mathrm{~m} / \mathrm{s}$ and corresponding depth of penetration value is $8,41 \mathrm{~mm}$. This sample verified as successful according to NIJ level II-A. In this sample carbon fiber fabric functioned as support plate cause fiber damage at directions $\pm 45^{\circ}$ because of it is $45^{\circ}$ and hard structured. Graphic of bullet velocity- depth of penetration that values taken from result of shots is given in Fig. 9.

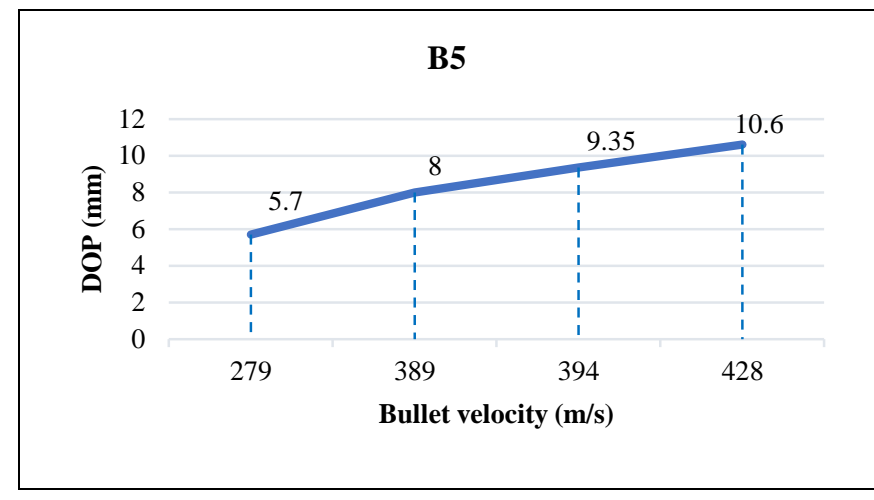

Figure 9. Graphic of bullet velocity-depth of penetration

After investigated of depth of penetration-bullet velocity graphic of B5 sample it is seen that while bullet velocity is raising depth of penetration is raising too as with previous samples

Ballistic test results of [Glass $\left(0^{\circ}\right) 7 /$ Aramid(plain) $7 /$ Carbon $\left.\left(0^{\circ}\right) 7\right]$ sequenced B6 sample is given in Fig. 10. Bullet velocity, kinetic energy and their assessment is given in Table 5.

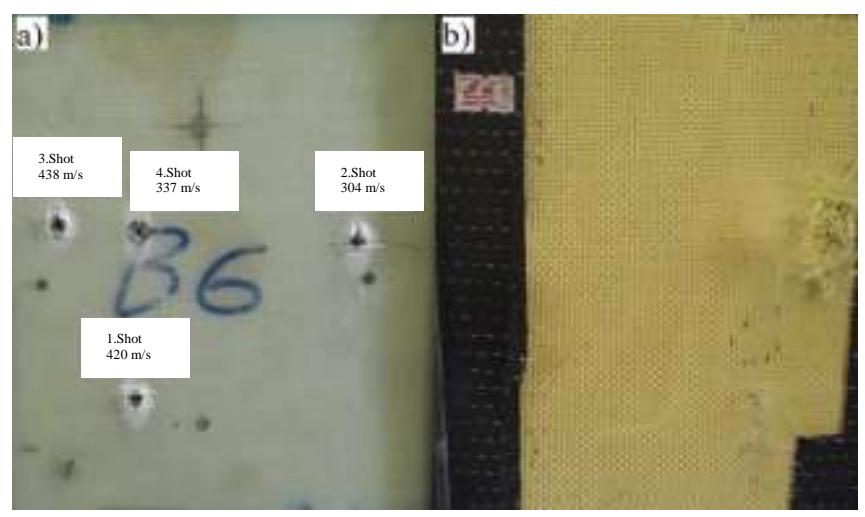

Figure 10. [Glass $\left(0^{\circ}\right)_{7} /$ Aramid (plain $\left.)_{7} / \operatorname{Carbon}\left(0^{\circ}\right)_{7}\right]$ test sample a) front view b) rear view

TABLE 6: Ballistic test result of B6 sample

\begin{tabular}{ccccc}
\hline \multicolumn{5}{c}{ Sample Sequence: $\left[\text { Glass }\left(\mathbf{4 5}^{\circ}\right)_{7} / \text { Aramid (plain }\right)_{7} /$ Carbon $\left.\left(45^{\circ}\right)_{7}\right]$} \\
\hline $\begin{array}{c}\text { Shot } \\
\text { Number }\end{array}$ & $\begin{array}{c}\text { Bullet } \\
\text { Velocity } \\
(\mathbf{m} / \mathbf{s})\end{array}$ & $\begin{array}{c}\text { Kinetic } \\
\text { Energy } \\
(\mathbf{N m})\end{array}$ & $\begin{array}{c}\text { Depth of } \\
\text { Penetration } \\
(\mathbf{m m})\end{array}$ & Evaluation \\
\hline 1 & 420 & 705,65 & 7,30 & No Perforation \\
2 & 304 & 369,39 & 5,80 & No Perforation \\
3 & 337 & 455,39 & 6,80 & No Perforation \\
4 & 438 & 768,44 & - & Perforation \\
Average & $\mathbf{3 5 4}$ & $\mathbf{5 1 0 , 1 4}$ & $\mathbf{6 , 6 3}$ & \\
\hline
\end{tabular}

Fourth shot have $438 \mathrm{~m} / \mathrm{s}$ one of 4 shots performed to sample B6 caused perforation. At back face carbon fiber plate with effect of crash rupture happened. Except shot number 4 other shots average depth of penetration value is $6,63 \mathrm{~mm}$ corresponding to average $354 \mathrm{~m} / \mathrm{s}$ bullet velocity. Shot number 4 perforation happened, fiber plates and leave the system by rupturing. Graphic of bullet velocity- depth of penetration is given in Fig. 11. 


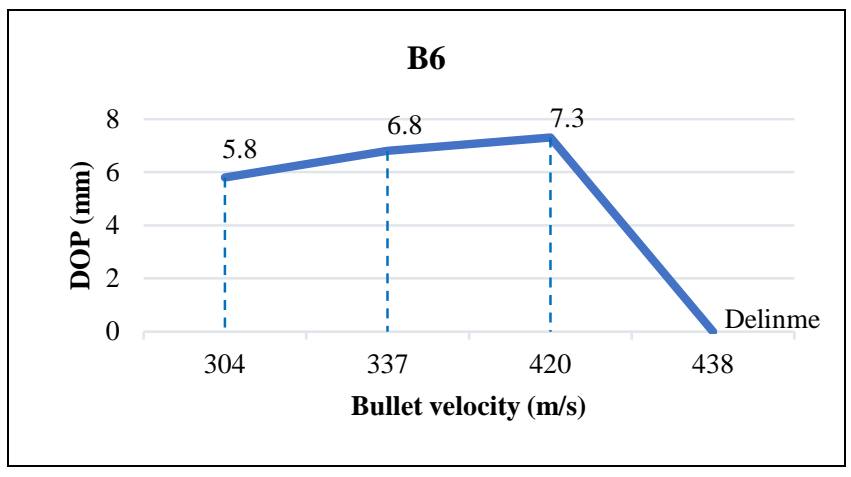

Figure 11. Graphic of bullet velocity-depth of penetration

As it understands from Fig. 11, in the shots they have no penetration there is parallelity between bullet velocity-depth of penetration. Shot number 1 that has highest velocity value has $420 \mathrm{~m} / \mathrm{s}$ in the shots they have no penetration and this is ballistic limit for his sample.

In the comparison with by heaviness and depth of penetration after ballistic tests between 3 sample their shots didn't result in perforation according to NIJ 0101-06 sample named B1 happened as the most successful sample with 5.53 $\mathrm{mm}$ average depth of penetration. Comparison of this three sample is given in Fig. 12.

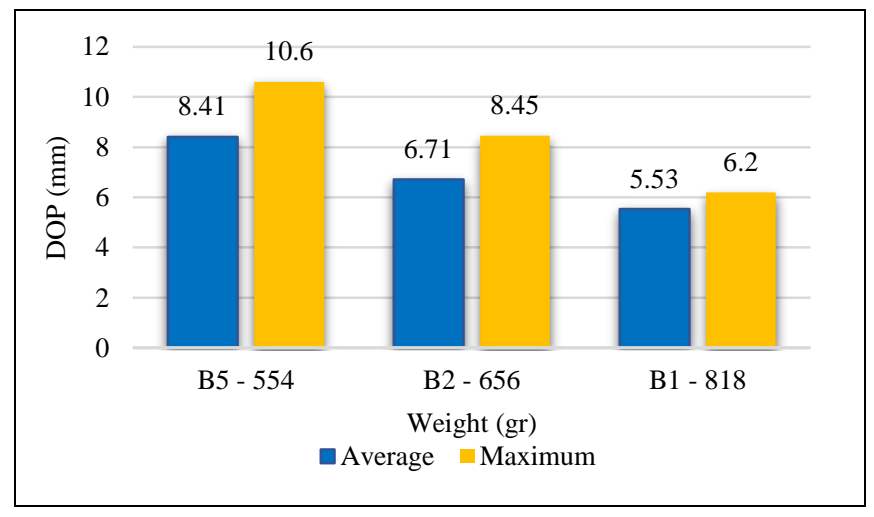

Figure 12. Graphic of weight-depth of penetration

B1 named sample is heaviest sample with $818 \mathrm{gr}$ and depth of penetration is 5,53. B2 sample that has 656 gr and depth of penetration value of it is $6,71 \mathrm{~mm}$. Between 3 Samples they verified as successful according to NIJ0101.06 standards, only 21 layered B5 sample has $554 \mathrm{gr}$ and average depth of penetration o this sample is $8,41 \mathrm{~mm}$.

\section{Conclusions}

In this study, test samples have been produced to investigate the usability of layered hybrid composites as personal armor material. Ballistic tests of these samples have been performed with the reference of NIJ.0101-06 standard and the results of the tests have been investigated. The structural configuration of the test sample and the evaluations of the ballistic test results are given in Table 7.

TABLE 7: The ballistic test results

\begin{tabular}{lllll}
\hline Name & Material & $\begin{array}{l}\text { Number } \\
\text { of layers }\end{array}$ & $\begin{array}{l}\text { Weight } \\
\text { [gr] }\end{array}$ & Evaluation \\
\hline B1 & {$\left[\right.$ Glass $\left(45^{\circ}\right) /$ Aramid } & 30 & 818 & II-A \\
\hline
\end{tabular}

\begin{tabular}{llccl}
\hline B2 & $\begin{array}{l}\left.\text { (plain)/Carbon }\left(45^{\circ}\right)\right] \\
{\left[\text { Glass }\left(0^{\circ}\right) / \text { Aramid }\right.} \\
\left.\text { (plain)/Carbon }\left(0^{\circ}\right)\right]\end{array}$ & 30 & 656 & II-A \\
B5 $\quad \begin{array}{l}\text { [Glass }\left(45^{\circ}\right) / \text { Aramid } \\
\left.\text { (plain)/Carbon }\left(45^{\circ}\right)\right]\end{array}$ & 21 & 554 & II-A \\
B6 $\quad$ & 21 & 468 & Perforation \\
& $\begin{array}{l}{\left[\text { Glass }\left(0^{\circ}\right) / \text { Aramid }\right.} \\
\left.(\text { plain }) / \text { Carbon }\left(0^{\circ}\right)\right]\end{array}$ & & & \\
\hline
\end{tabular}

B1 with [Carbon $\left(45^{\circ}\right)_{10} /$ Aramid (Plain) $)_{10} /$ Glass $\left(45^{\circ}\right)_{10}$ ] lineup has been observed to be the most successful of 30 layered test samples in the ballistic tests.

After observing success of 30 layered hybrid composites in the ballistic tests, the layer number has been decreased to 21 from 30 and the ballistic tests have been performed for these samples.

In 21 layered samples only sample B5 verified as successful.

By considering the results of all test, $45^{\circ}$ unidirectional fabrics have been determined to have better ballistic resistance from $0^{\circ}$ unidirectional fabrics.

The damage types have been investigated after the ballistic tests and damage of fiber and separation of layers have been observed to be the most common damage types.

Behind the protection property, another important factor in the design of armor material is lightness property. The successful test samples of the ballistic tests in this study can be recommended to study to reach an optimum weight and thickness with better ballistic resistance by reducing the number of layers for new armors.

\section{References}

[1] Othman AR, Hassan MH. Effect of different construction designs of aramid fabric on the ballistic performances. Mater Des 2013;44:40713.

[2] National Institue of Justice 0101.06 (2005) Ballistic Resistance of Body Armor

[3] Kedzierski, P., Gieleta, R., Morka, A., Niezgoda, T., Surma, Z., Experimental study of hybrid soft ballistic structures, Composite Structures 153 (2016) 204-211.

[4] National Institue of Justice 0101.06 (2005) Ballistic Resistance of Body Armor

[5] Mines, R.A.W., Roach, A.M., Jones N., 1999. High velocity behaviour of polymer composite laminates. International Journal of Impact Eng, 22, 561-588.

[6] Gustın, J., Joneson, A., Mahınfalah, M., Stone, J., "Low velocity impact of combination Kevlar/carbon fiber sandwich composites", Composite structures, 2005, 69: 396-406.

[7] Yanen, C., "Tabakalı Hibrit Kompozitlerin Bireysel Zırh Malzemesi Olarak Kullanılabilirliğinin Araştırılması” 2016, Yüksek Lisans Tezi, Fırat Üniversitesi, Fen Bilimleri Enstitüsü, Elazığ.

[8] Yanen, C., Solmaz, M.Y., "Tabakalı Hibrit Kompozitlerin Bireysel Zırh Malzemesi Olarak Üretimi ve Balistik Performanslarının İncelenmesi", 2016, El Cezeri Bilim ve Mühendislik Dergisi;Cilt 3;Sayı 2;351-362

Candan, C., Akdemir, A., 2004. An investigation of terminal ballistic properties and design of composite armor against the light weapons, 10. Denizli Malzeme Sempozyumu ve Sergisi, 147-154.

About Author (s):

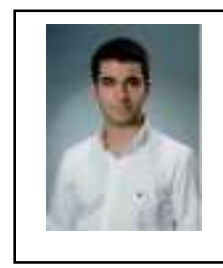

Cenk YANEN received the BSc degree in Mechanical Engineering from Mersin University, Mersin, Turkey in 2010, and the MSc degree from Firat University, Elazig, Turkey in 2016. He is currently continuing his study in $\mathrm{PhD}$ degree at Firat University, Elazig, Turkey. His research interests include mechanic, composite material. $\mathrm{He}$ is Research Assistant at department of Mechanical Engineering of Firat University. He is married and have one children. 